\title{
Front Matter: Volume 11818
}

, "Front Matter: Volume 11818," Proc. SPIE 11818, Laser Beam Shaping XXI, 1181801 (24 August 2021); doi: 10.1117/12.2606380

SPIE Event: SPIE Optical Engineering + Applications, 2021, San Diego, California, SPIE. United States 


\section{PROCEEDINGS OF SPIE}

\section{Laser Beam Shaping XXI}

Angela Dudley

Alexander V. Laskin

Editors

1-5 August 2021

San Diego, California, United States

Sponsored by and Published by

SPIE 
The papers in this volume were part of the technical conference cited on the cover and title page. Papers were selected and subject to review by the editors and conference program committee. Some conference presentations may not be available for publication. Additional papers and presentation recordings may be available online in the SPIE Digital Library at SPIEDigitalLibrary.org.

The papers reflect the work and thoughts of the authors and are published herein as submitted. The publisher is not responsible for the validity of the information or for any outcomes resulting from reliance thereon.

Please use the following format to cite material from these proceedings:

Author(s), "Title of Paper," in Laser Beam Shaping XXI, edited by Angela Dudley, Alexander V. Laskin, Proc. of SPIE 11818, Seven-digit Article CID Number (DD/MM/YYYY); (DOI URL).

ISSN: 0277-786X

ISSN: 1996-756X (electronic)

ISBN: 9781510644748

ISBN: 9781510644755 (electronic)

Published by

SPIE

P.O. Box 10, Bellingham, Washington 98227-0010 USA

Telephone +1 3606763290 (Pacific Time)

SPIE.org

Copyright (C) 2021 Society of Photo-Optical Instrumentation Engineers (SPIE).

Copying of material in this book for internal or personal use, or for the internal or personal use of specific clients, beyond the fair use provisions granted by the U.S. Copyright Law is authorized by SPIE subject to payment of fees. To obtain permission to use and share articles in this volume, visit Copyright Clearance Center at copyright.com. Other copying for republication, resale, advertising or promotion, or any form of systematic or multiple reproduction of any material in this book is prohibited except with permission in writing from the publisher.

Printed in the United States of America by Curran Associates, Inc., under license from SPIE.

Publication of record for individual papers is online in the SPIE Digital Library.

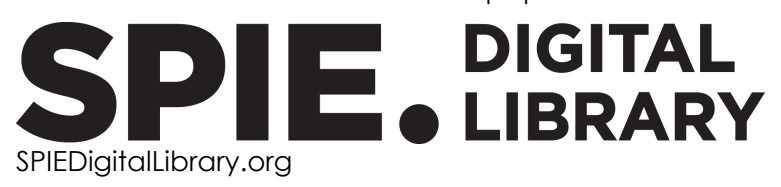

Paper Numbering: A unique citation identifier (CID) number is assigned to each article in the Proceedings of SPIE at the time of publication. Utilization of CIDs allows articles to be fully citable as soon as they are published online, and connects the same identifier to all online and print versions of the publication. SPIE uses a seven-digit CID article numbering system structured as follows:

- The first five digits correspond to the SPIE volume number.

- The last two digits indicate publication order within the volume using a Base 36 numbering system employing both numerals and letters. These two-number sets start with 00, 01, 02, 03, 04, 05, 06, 07, 08, 09, OA, OB ... 0Z, followed by 10-1Z, 20-2Z, etc. The CID Number appears on each page of the manuscript. 


\section{Contents}

VORTEX BEAMS AND OAM

1181802 Structured light towards multiple degrees of freedom and higher dimensions (Invited Paper) [1 1818-1]

1181803 Arbitrary-order vortex lattice and linear vortex array formed by the superposition of two edge dislocation fields [1 1818-2]

$1181805 \quad$ Analysis of spatio-temporal properties of ultrashort optical vortices [1 1818-4]

1181806 Modal decomposition of a partially coherent Ince-Gaussian beams [11818-5]

1181807 Free-space local nonseparability dynamics of parabolic vector modes [11818-23]

$1181808 \quad$ Accelerating vector beams along parabolic trajectories [11818-24]

POLARIZATION AND QUANTUM OPTICS

$1181809 \quad$ Knotted topologies in the polarization state of bichromatic light (Invited Paper) [1 1818-6]

$11818 \mathrm{OB} \quad$ Digitally controlled ray-wave geometric beams as higher-dimensional information carriers [11818-8]

HIGH-POWER BEAM SHAPING

$118180 \mathrm{C}$ Amplification of a propagation invariant vector flat-top beam [11818-10]

11818 OD Determination of amplification characteristics in end-pumped solid-state amplifiers [11818-11]

MATERIALS PROCESSING

$11818 \mathrm{OE} \quad$ Optical materials for blue-laser processing [11818-12]

11818 OF Through-focus spot shaping with asymmetric pupil optimization for laser stealth dicing [11818-13] 
ADAPTIVE OPTICS AND APPLICATIONS

11818 OG Phase optimization for tiled spatial light modulators [1 1818-14]

SPATIAL AND TEMPORAL SHAPING

$1181801 \quad$ Simulating the branched flow of light [1 1818-17]

$118180 \mathrm{~K}$ Optical soliton generation in a photorefractive Fe-doped lithium niobate crystal by a pyroelectric effect [11818-19]

$11818 \mathrm{OL}$ To unify travelling- and standing-wave ray-wave structured light by coherent wave packets [11818-20]

$118180 \mathrm{M}$ Spatial intensity correlations of the speckle pattern of a Mathieu beam [11818-21]

\section{POSTER SESSION}

$11818 \mathrm{ON} \quad$ B-spline approximation of a wavefront measured by Shack-Hartmann sensor [11818-15]

1181800 Comparison of stacked actuator and bimorph mirrors for scattered laser-beam focusing [11818-22]

iv 